\title{
Crocheted Indonesian Language Learning with the Environment
}

\author{
Mutiara Pardini Ningrum/19016035 \\ mutiarapardinin@gmai.com
}

The communication language is required. In its application, the language has an important role in human life. Therefore, human behavior and culture of a nation can be seen from the language used. Bahasa Indonesia has a high status, because of the Indonesian language is the official language of the nation of Indonesia. For that, the application of Indonesian language can be taught from an early age from the environment, whether that environment is formal or informal in order to instill the values of life and social early on.

Indonesian language learning is closely related to the surrounding environmental conditions. The environment has a great influence in a child's language development. In the form of formal, material environment can be put in the Indonesian language learning at school. The teacher can make the link between the texts that exist in Indonesian language learning by example environment. The introduction of environmental education is important to put in the learning in order to foster awareness of students in keeping the surrounding environment. It is also in accordance with the Ramadan et.al (2019), who said that environmental education is important to improve the attitude and awareness of students towards the environment. Environmental education can make students to think critically and contextually. How to think critically and contextually this effect later on Indonesian language learning, so between environmental education and language learning are interrelated. Sukma (2005), said the use of language is closely related to the social relations between speakers that are in the middle of the community.

According to Ramadan et.al (2018), a model of innovative learning is able to improve the learning outcomes of students, the integration of environmental education in the process of learning Indonesian language is one way in realizing and developing the ability of students so that 
the students can innovate and collaborate with the environment around them. Resumed, according to Ramadan et.al (2019), the institution of education as the key stakeholders required to increase the environmental awareness of students. In Indonesia, environmental education is not a lesson at school. Therefore, education-based environment can be applied in other subjects, such as the Indonesian language subjects. Ramadan et.al (2019), revealing that the use of the environmental theme in the learning-based text can trigger students 'interest in learning the language and implicitly able to increase students' knowledge about the environment.

Sukma (2017), says the ability in berliterasi have a significant influence on the success of students in learning and everyday life. Literacy skills are better, it will help students in understanding the text of oral, written, and visual text. According to the Soul (2019), teachers should provide motivation to the students. Through motivation, a teacher can create a variety of learning experiences for students. Indriyani et.al (2019), says literacy students need to be improved especially the literacy to read and write. Then, also need to know how the implementation of literacy that have been implemented in the school. According to the Sukma (2020), the planting of the important characters introduced since the students still in elementary school. Planting a character can do in the learning process at school. The multiplicity of the diversity of the characters and habits of the students at the school come from the family background is a major influence causing bad things of the children's characters are bad.

According to Hartidini et.al (2018), literacy is at the heart of the ability of students to succeed in learning at school and also to face the various challenges in the future. The quality of Indonesian language learning in ligkungan school is influenced by the method of learning that is applied by the teacher, and students ' interest in learning. The princess and the Syahrul (2019), revealed that in teaching and learning in the school environment, the teaching of reading must obtain a serious concern of educators in Indonesia. Through teaching, educators are able to steer the learners in language learning. Sari et.al (2018),say read in communicative used to search for, find, and obtain information from various sources in accordance with the understanding of each individual is obtained.

Therefore, it is necessary to do a questionnaire to determine the percentage level of relationship or association between the Indonesian language learning with the social environment of the students. This questionnaire aims to determine the levels of the four options from the results 
of the statements that have been presented to respondents in the form of UNP students of semester 5. Overall the respondents were 30 people. The results of the data of the percentage of the questionnaire that has been done through the google form can be seen as follows.

The first statement, the introduction of the environment is very influential on the language learning Indonesia, persenta senya show strongly agree 93, 3 and 7\%, $7 \%$ agreed. The second statement, Indonesian language learning has an important role to develop the knowledge about the environment, environmental awareness, and behavior change to the environment, the percentage obtained from the questionnaire that $83,3 \%$ stated strongly agree and $16.7 \%$ agree. The third statement, the environment is used as a source of inspiration to build the intelligence of the language, the percentage 44, $8 \%$ stated strongly agree and 55, 2\% agree. Statement of the fourth, learning-based environment aimed at making students participate in maintaining and protecting approximately, the percentage obtained which is $30 \%$ stated strongly agree, and $70 \%$ agree. Then the statement of the fifth, in Indonesian language learning, teachers should use the text-the text of the themed environment, the percentage obtained $66,7 \%$ stated strongly agree and $33,3 \%$ who agree. Statement sixth, one way to create a conducive atmosphere for learning can be done by using the environment to develop the activity and creativity of learning optimally, the percentage of this statement of the results of the questionnaire that of $63.3 \%$ stated strongly agree, and 11, $3 \%$ agree. Statement of the seventh, the ability to speak and understand the language is influenced by environmental factors, the percentage showed 46, $7 \%$ strongly agreed, 50\% agreed, and $4.2 \%$ less agree. Statement of the eighth, the teacher has an important role in introducing environmental education through learning in the class, the percentage showed 53.3\% stated strongly agree, $40 \%$ agree, and $7.7 \%$ less agree. Statement of the ninth, in the relation between the Indonesian language learning environment, students can observe what there is in the environment. Then make these observations as a source of inspiration for making one of the literary work in the form of a text report on the results of observation, the percentage of this statement is that $53.3 \%$ of stated strongly agree, and 46, 7\% agree. Statement of the tenth, the utilization of the learning environment is expected to help the process of development of the individual into a social being who can adapt degan better in its environment, the percentage of this statement, namely $60 \%$ stated strongly agree, $36,7 \%$ declares to agree and 4, 3\% less agree. 
Based on the results of the research that has been conducted by the author, it can be concluded that environmental education is closely related to the Indonesian language learning. Therefore, through the environment, students are able to develop the ability of ecological, creative thinking, innovative, and able to increase the student's awareness of the importance of protecting the environment. In addition, the atmosphere in the school environment should be optimized as much as possible so that students feel at home and comfortable while learning English. With the presence of learning-themed environment can make the students have the awareness to always keep the environment, care for the environment, preserve the environment, and learn from the environment. The author hopes that the implementation of learning that use of the material environment in education at school can make learning a love of the environment. With the presence of learning-themed environment can expand the knowledge, views, and thought better of it teachers or students to always learn from the environment. In addition, the material environment is a topic of interest to be studied, especially in learning English. Efforts to conserve the environment can be inserted in the text-reading text bahasa Indonesia. Teachers can imply Indonesian language learning with the environment one by searching for relevant examples so that students are more familiar with the material given. 


\section{KEPUSTAKAAN}

Hartidini S, Syahrul R, and Pandu R. (2018). The influence of Learning Strategies, InquiryBased Audiovisual Media on essay Writing Skills of Argumentation Students of Class X SMA Negeri 2 Lengayang South Coastal District. Journal of Indonesian Language and Literature Education, Vol.1 No.7, 63-69.

Putri D, and Syahrul R. (2019). The correlation of Reading Comprehension Skills and Writing Skills Text of the Report the Observation Result of Students of Class VII SMP Negeri 4 Pariaman. Journal of Indonesian Language and Literature Education, Vol. 8 No.1, 6269.

Sukma E. (2005). The application of Communicative Approach in Learning the Structure of the Indonesian Language in Elementary School. Diction, Vol.12 No.1, 108-117.

Sukma E. et.al. (2019). Problems in Oral Language Teaching in Primary School. Advances in Social Science. Education and Humanities Research, Volume 301, 194-200.

Sukma E, Ritawati M, and Rizky A. (2017). Literacy Media Development in Improving Reading and Writing Skills of Early Class Students in Elementary School North Padang Padang. Advances in Social Science, Education and Humanities Research, Vol 118, 3-9.

Sukma E, and VP Azrianti. (2020). Instilling Positive Characters in Students Using Folker in the Macromedia Application. Advances in Social Science, Education and Humanities Research, Volume 485, 30-40.

Ramadan S, Asri Y, and V Indriyani . (2018). Learning Module Design Writing Argumentative Text Based Problem-Based Learning. In Advances in Social Science:Education and Humanities Research, Vol 263:194-200.

Ramadan S, Sukma E, and V Indriyani. (2019). Environmental Education and Disaster Mitigation Through Languange Learning. IOP Conference Series: Earth and Environmental Science, 314-315.

Indriyani V, Zaim M., Atmazaki, and Syahrul R. (2019). The literacy to Read and Write and Innovation Language Curriculum. The wanderer: the Journal of the Science of Language, Literature, and Teaching, Vol 5 (1):108-118. 
Sari Y, Syahrul R, and Yulianti R. (2018). Relationship Between Reading Comprehension Skills with the Skills to Write the Text of the Report the Observation Result of Students of Class X SMK Negeri 3 Padang. Journal of Indonesian Language and Literature Education, Vol.7, No.3; series F446-453. 